Türk Tarım ve Doğa Bilimleri Dergisi 6(3): 489-493, 2019

https://doi.org/10.30910/turkjans.595363

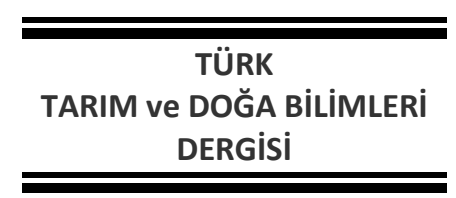

\title{
Olgunlaşma Dönemlerinin Sirken (Chenopodium album) Otunun Kimyasal Kompozisyonuna, Besleme Değerine ve Metan Üretimine Etkisi
}

\author{
Ali Ihsan ATALAY ${ }^{1 *}$, Adem KAMALAK² \\ ${ }^{1}$ Iğdır Üniversitesi Ziraat Fakültesi Zootekni Bölümü \\ ${ }^{2}$ Kahramanmaraş Sütçü İmam Üniversitesi Ziraat Fakültesi Zootekni Bölümü \\ *Sorumlu yazar: aliihsanatalay66@hotmail.com
}

Geliş Tarihi: 28.03.2019

Düzeltme Geliş Tarihi: 28.06.2019

Kabul Tarihi: 01.07.2019

\section{Özet}

Bu çalışmanın üç farklı zamanda hasat edilen sirken otunun (Chenopodium album) besleme değerini kimyasal kompozisyon ve gaz üretim tekniği kullanarak belirlemektir. Hasat zamanı Sirken otunun kimyasal kompozisyonunu önemli derecede etkilemiştir. Sirken otunun olgunlaşmasılyla beraber asit deterjan fiber (ADF) ve nötral deterjan fiber (NDF) içerikleri artarken, ham protein (HP), ham kül (HK) ve ham yağ (HY) içerikleri azalmıştır. Sirken otunun ADF ve NDF içerikleri sırasıyla \% 23.56 ile 36.82 ve \% 40.27 ile 52.64 arasında değişmiştir. Diğer taraftan Sirken otunun HP içeriği ise \% 8.44 ile 19.32 arasında değişmiştir. Sirken otunun in vitro gaz üretim değerleri 28.93 ile $39.53 \mathrm{ml}$ arasında değişmiştir. Olgunlaşma dönemlerinin ilerlemesiyle Sirken otunun besleme değeri düşmüştür. Olgunlaşma dönemlerinden ilk iki dönemde Sirken otunun ham protein ve metabolik enerji bakımından çok iyi derecede olduğu tespit edilmiştir. Bu yüzden ilk iki dönemde hasat edilen Sirken otu ruminant hayvanların protein ve metabolik enerji ihtiyacını karşılamak için rasyonlara katılabilir.

Anahtar kelimeler: Sirken otu, kimyasal kompozisyon, sindirilebilirdik, metabolik enerji, besleme değeri, metan.

\section{Effect of Maturity Stages on Chemical Composition, Nutritive Value and Methane Production of Chenopodium album Hay}

\begin{abstract}
The aim of current experiment was to determine nutritive value of Chenopodium album hay harvested at three harvest stages using chemical composition and in vitro gas production technique. Harvest stage significantly affected the chemical composition of Chenopodium album hay. ADF and NDF contents of Chenopodium album hay increased with advancing maturity while crude protein, crude ash and ether extract were decreased. ADF and NDF contents of Chenopodium album hay ranged from 23.56 to 36.82 and 40.27 to $52.64 \%$ respectively. On the other hand, crude protein contents of Chenopodium album hay ranged from 8.44 to $19.32 \%$. In vitro gas production of Chenopodium album hay ranged from 28.93 to $39.53 \mathrm{ml}$. Potential nutritive value of Chenopodium album hay decreased with advancing maturity. Crude protein and metabolisable energy of Chenopodium album hay at first two stages were considerable well. Therefore Chenopodium album hay at first two stages can be included into ruminant diets to meet protein and metabolisable energy.
\end{abstract}

Key words: Chenopodium album hay, chemical composition, digestibility, metabolisable energy, nutritive value, methane. 
Giriş

Dünya'nın birçok yerinde olduğu gibi Türkiye'de de meradaki otların ruminant hayvanların beslenmesinde enerji, protein ve mineral sağlaması açısından önemli bir rolü vardır. Bu yemler ayrıca çiğneme ve ruminasyon için ruminant hayvanlara lif sağlarlar. Iğdır ve çevresinde salmanca olarak isimlendirilen, Sirken bitkisi (Chenopodium album L. ) Chenopodiaceae (Ispanakgiller) familyasından genellikle 150 ila $200 \mathrm{~cm}$ kadar boylanan Türkiye'de farklı yörelerde Ak Kazayağı, Ak Pazı ve Sirken olarak isimlendirilen ve yabani ıspanak olarak adlandırılan tek yıllık otsu bir bitkidir. (Davis, 1965; Uygur ve ark., 1986; Guerrero ve ark., 1997; Baytop, 1999; Özer ve ark., 1999; Anwar, 2006). Tarımsal ya da tarımsal olmayan alanlarda yetişen, insanlar ve hayvanlar tarafından tüketilen yabancı ottur (Bhargava ve ark., 2003a,b). Son zamanlarda bazı araştırmacılar tarafından merada otlayan hayvanların spesifik ihtiyaçlarının karşılanması konusunda meradaki bazı ot türlerinin büyüme evresindeki besin değerlerinin belirlenmesiyle ilgili çalışmalar yapılmasına rağmen (Kamalak ve Canbolat, 2010; Kamalak ve ark., 2011; Kaplan ve ark., 2014a, b) doğal meralarda yetişen Sirken otunun besleme değeri hakkındaki yapılan çalışmalar sınırlıdır. Kimyasal kompozisyon, in vitro gaz üretimi, Organik Madde Sindirim Derecesi (OMSD) ve Metabolik Enerji (ME) içerikleri daha önce kısıtlı araştırılmış veya araştırılmamış olan yemlerin potansiyel besin değerini belirlemek için yaygın olarak birlikte kullanılmış yöntemlerdir. (Kamalak ve Canbolat, 2010; Kamalak ve ark., 2011; Canbolat 2012; Guven 2012; Kaya ve Kamalak, 2012).

Bu çalışmanın amacı, üç farklı zamanda hasat edilen sirken otunun (Chenopodium album) kimyasal kompozisyon, in vitro gaz üretimi, metabolik enerji ve organik madde sindirim derecesi ile metan üretim kapasitesini belirleyerek bu bitkinin potansiyel besleme değerini ortaya çıkarmaktır.

\section{Materyal ve Yöntem}

Sirken otunun kurutulması, öğütülmesi ve kompozisyonunun belirlenmesi

Yapılan çalışmada Sirken bitkisi (Chenopodium album) 2018 yılında Mayıs-Haziran aylarında Iğdır Üniversitesi Suveren kampüsü içerisinde doğal olarak yetişmektedir. Kampüs içerisinden üç farklı olgunlaşma döneminde (ilk dönem çiçeklenme öncesi, ikinci olarak çiçeklenme dönemi ve son olarak tohum bağlama dönemi) zeminden 3-5 cm yukarıdan makas vasıtası ile elle hasat edilmiştir. Hasat edilen örnekler beklenmeden laboratuvara getirilerek kuru maddeleri (KM) belirlenmiş kalan örnekler diğer analizlerde kullanılmak üzere gölgede kurutulduktan sonra $1 \mathrm{~mm}$ elekten geçecek şekilde çekiçli değirmen yardımı ile öğütülerek sonraki analizler için hazır hale getirilmiştir. Sirken otunun KM içerikleri $105{ }^{\circ} \mathrm{C}^{\prime}$ lik etüvde bir gece tutularak, ham kül içerikleri ise kül fırınında $550^{\circ} \mathrm{C}^{\prime}$ de 8 saat yakılarak belirlenmiştir. Azot (N) içerikleri Kjeldahl metoduna göre belirlenmiştir (AOAC, 1990). Sirken otunun ham protein içerikleri ise analiz sonucu elde edilen azot değerinin 6.25 kat sayısı ile çarpılması sonucunda elde edilmiştir. Sirken otunun hücre duvarı içerikleri (ADF ve NDF) Van Soest ve ark., (1991) tarafından yapılan metoda göre belirlenmiştir.

\section{Sirken otunun gaz ve metan içeriklerin belirlenmesi}

Yaklaşık 0.200 g örnek 24 saat boyunca $39{ }^{\circ} \mathrm{C}$ sıcaklıktaki su banyosunda Menke ve ark. (1979) metodu kullanılarak 3'er tekerrürlü olacak şekilde tamponlanmış rumen sıvısı ile inkübasyona bırakılmıştır. Rumen sıvısı günde iki kez (\%60) yonca samanı ve (\% 40) kesif yem karışımı içeren rasyon ile beslenen fistüllü üç koyundan alınmıştır. Örneklerin net gaz üretimi 24 saatlik inkübasyon sonucunda belirlenmiş, kontrol ve standart örneğe (University of Hohenheim, Germany) göre düzeltilerek hesaplanmıştır. İnkübasyon sonucu elde edilen gazlar metan yüzdelerini belirlemek için plastik şırıngalar ile Infrared Metan Analiz cihazına (Sensor Europe $\mathrm{GmbH}$, Erkrath, Germany) aktarılarak belirlenmiştir (Goel ve ark. 2008). Örneklerin metan gazı üretim miktarları aşağıda verilen formül kullanılarak hesaplanmıştır.

Metan gazı üretim miktarı $(\mathrm{ml})=$ Toplam üretilen gaz $(\mathrm{mL})$ x Metan üretim (\%)

Sirken otunun metabolik enerji içeriği (MJ/kg KM) ve organik madde sindirim dereceleri (OMSD) Menke ve Steingass (1988) tarafından bildirilen eşitlik kullanılarak hesaplanmıştır:

$$
\begin{aligned}
& \text { ME }(\mathrm{MJ} / \mathrm{kg} \mathrm{KM})=1.68+0.1418 \mathrm{GÜ}+0.073 \mathrm{HP} \\
& +0.217 \mathrm{HY}-0.028 \mathrm{HK} \\
& \text { OMSD }(\%)=14.88+0.8893 \mathrm{GÜ}+0.448 \mathrm{HP}+ \\
& 0.651 \mathrm{HK} \\
& \text { Bu eşitliğe göre; } \\
& \text { GÜ }=(\mathrm{ml} / 200 \mathrm{mg}) 24 \text { saat sonundaki net gaz } \\
& \text { üretimi } \\
& \text { KM }=(\%) \text { Kuru Madde } \\
& \mathrm{HP}=(\%) \text { Ham protein } \\
& \text { HY }=(\%) \text { Ham yağ } \\
& \text { HK }=(\%) \text { Ham kül } \\
& \text { ME }=(\mathrm{MJ}) \text { Metabolik Enerji } \\
& \text { OMSD: (\%) Organik madde sindirim derecesi }
\end{aligned}
$$




\section{istatistiksel analiz}

Olgunlaşma dönemlerinin Sirken otunun besin madde kompozisyonuna, in vitro gaz üretimine, metan üretimine, metabolik enerji içeriğine ve organik madde sindirim derecesine olan etkisini araştırmak için varyans analizi (One-way ANOVA), ortalamaların karşılaştırılması ise çoklu karşılaştırma testlerinden Tukey testi kullanılarak yapılmıştır.
Bulgular ve Tartışma

Olgunlaşma dönemlerinin sirken (Chenopodium album) otunun kimyasal kompozisyonuna etkisi

Olgunlaşma dönemlerinin Sirken otunun kimyasal kompozisyonuna olan etkisi Çizelge 1'de görülmektedir. Olgunlaşma Sirken otunun kimyasal kompozisyonunu önemli derecede etkilemiştir.

Çizelge 1. Olgunlaşma dönemlerinin Sirken otunun (Chenopodium album) kimyasal kompozisyonuna olan etkisi

\begin{tabular}{cccccc}
\hline \multicolumn{7}{c}{ Hasat zamanı } \\
\hline Parametreler & Çiçeklenme öncesi & Çiçeklenme dönemi & Tohum bağlama & SHO & Ö S \\
\hline KM & $19.27^{\mathrm{c}}$ & $25.67^{\mathrm{b}}$ & $32.87^{\mathrm{a}}$ & 0.662 & $* *$ \\
HK & $18.26^{\mathrm{a}}$ & $18.91^{\mathrm{a}}$ & $9.58^{\mathrm{b}}$ & 0.426 & $* *$ \\
HP & $19.32^{\mathrm{a}}$ & $16.48^{\mathrm{b}}$ & $8.44 \mathrm{c}$ & 0.478 & $* *$ \\
HY & $2.32^{\mathrm{ab}}$ & $2.51^{\mathrm{a}}$ & $2.03^{\mathrm{b}}$ & 0.076 & $*$ \\
NDF & $40.27^{\mathrm{c}}$ & $45.91^{\mathrm{b}}$ & $52.64^{\mathrm{a}}$ & 0.622 & $* *$ \\
ADF & $23.56^{\mathrm{c}}$ & $29.31^{\mathrm{b}}$ & $36.82^{\mathrm{a}}$ & 0.944 & $* *$ \\
\hline
\end{tabular}

abc Aynı satırda bulunan farklı simgelere sahip ortalama değerler birbirinden farklıdır (P<0.05); SHO: Standard hata ortalaması; Ös: Önem seviyesi.

Sirken otunun olgunlaşmasıyla beraber NDF ve ADF içerikleri artarken HK, HP ve HY içerikleri azalmıştır. Sirken otunda en düşük NDF oranı (\%40.27) çiçeklenme öncesi dönemde bulunurken en yüksek (\%52.64) tohum bağlama döneminde, ADF oranında da en düşük değer (\%23.56) çiçeklenme öncesi dönemde en yüksek ise (\%36.82) tohum bağlama döneminde bulunmuştur. Sirken otunda hasat döneminin gecikmesiyle HP oranı \%19.32'den \%8.44'e düşüş olduğu tespit edilmiştir. Ham kül oranları \%18.26-9.58, ham yağ oranı ise \%2.32-2.03 arasında değişim göstermiştir. Olgunlaşma döneminin ilerlemesiyle bitki bünyesindeki yaprak dal oranının değişmesi ile KM içeriği 19.27'den 32.87 'ye kadar yükselmiştir. Bu sonuç Kamalak ve ark., (2011), Kaplan ve ark., (2014a) tarafından bildirilen değerlerde olduğu gibi HP içeriğindeki azalma bitkinin olgunlaşması ile hücre duvarı içeriği KM, NDF ve ADF değerlerindeki artış ile uyum içerisindedir. Sirken otunun ham protein içeriğinin azalmasına ters orantılı olarak hücre duvar içeriğindeki artışın büyük olasılıkla bitkinin olgunlaşması, sap oranın artmasıyla beraber yapraklardaki azalmayla ilişkilidir. Yapraklar; yonca otunun olgunlaşmasıyla sap oranını önemli derecede etkilemiş ve 0.59 dan 0.27'ye düşürmüştür (Stavarache ve ark., 2015). Diğer bir ifadeyle protein bakımından zengin yaprak miktarının azalmasıyla, protein oranının düşük olduğu sap miktarının artması bitkideki toplam protein miktarını azalttığı düşünülmektedir (Buxton, 1996). Yapraklar sap ile karşılaştırıldığında proteince zengin hücre duvarı içeriği bakımından fakirdir. Bu nedenle bitkinin olgunlaşmasıyla beraber ham protein yerine hücre duvarı içeriğindeki artış kaçınılmazdır.

Olgunlaşma dönemlerinin sirken otunun in vitro gaz üretim değerlerine, metabolik enerji (ME) içeriğine ve organik madde sindirim derecesi (OMSD) üzerine etkisi

Olgunlaşma dönemlerinin Sirken otunun in vitro gaz üretimi $(\mathrm{ml})$, metan $(\mathrm{CH} 4 \%, \mathrm{ml}), \mathrm{ME}$ ve OMSD'ne olan etkisi Çizelge 2'de verilmiştir. Sirken otunun in vitro gaz üretimi 28.93-39.53 ml, ME içerikleri 6.63-8.69 MJ/kg KM, OMSD ise \%50.6370.57 arasında değişim göstermiş olup, çiçeklenme öncesinden tohum bağlama dönemine geçince azalış meydana gelmiştir. Sirken otunun fermantasyonu sonucunda çıkan metan içeriği \% 15.61 ile 19.35 arasında değişmiş, üretilen metan miktarı 5.52 ile 6.35 $\mathrm{ml}$ olarak bulunmuştur. Olgunlaşmanın artmasıyla beraber in vitro gaz üretimi, ME ve OMSD azalırken, metan $\left(\mathrm{CH}_{4}\right)$ üretim miktarları her ne kadar \% olarak arttığı görülse de toplam gaza oranlandığında metan üretimi (ml) azaldığı görülmektedir.

Bazı araştırmacılar farklı olgunlaşma dönemlerinde hasat edilen Astragalus türleri, Trifolium angustifolium, Trigonella kotschi, Sanguisorba minor ve Onobrychis caput-galli otlarında da benzer şekilde trend gösteren ME ve OMSD değerlerine ulaşmışlardır (Cacan ve ark., 2017; Kamalak ve Canbolat, 2010; Kamalak ve ark., 2011; Kaplan ve ark., 2014a,b). Gaz üretimi, ME ve OMSD değerleri fermente olabilen substrat miktarı ile pozitif ilişkilidir. Daha önce de bahsedildiği gibi, 
Chenopodium album otunun olgunlaşmasıyla beraber ham proteinin yerine hücre duvarı içeriği artmıştır.

Çizelge 2. Olgunlaşma dönemlerinin Sirken otunun in vitro gaz üretim değeri, metabolik enerji içeriği ve organik madde sindirim derecesi üzerine etkisi

\begin{tabular}{cccccc}
\hline & \multicolumn{5}{c}{ Hasat zamanı } \\
\hline Parametreler & Çiçeklenme öncesi & Çiçeklenme dönemi & Tohum bağlama & SHO & Ö S \\
\hline Gaz Üretimi $(\mathrm{ml})$ & $39.53^{\mathrm{a}}$ & $35.39^{\mathrm{b}}$ & $28.93^{\mathrm{c}}$ & 0.567 & $* *$ \\
$\mathrm{CH}_{4}(\mathrm{ml})$ & $6.35^{\mathrm{a}}$ & $5.52^{\mathrm{b}}$ & $5.59^{\mathrm{b}}$ & 0.113 & $* *$ \\
$\mathrm{CH}_{4}(\%)$ & $16.05^{\mathrm{b}}$ & $15.61^{\mathrm{b}}$ & $19.35^{\mathrm{a}}$ & 0.354 & $* *$ \\
$\mathrm{ME}$ & $8.69^{\mathrm{a}}$ & $7.97^{\mathrm{b}}$ & $6.63^{\mathrm{c}}$ & 0.075 & $* *$ \\
OMSD & $70.57^{\mathrm{a}}$ & $66.05^{\mathrm{b}}$ & $50.63^{\mathrm{c}}$ & 0.576 & $* *$ \\
\hline
\end{tabular}

$\overline{\mathrm{abc}}$ Aynı satırda bulunan farklı simgelere sahip ortalama değerler birbirinden farklıdır (P<0.05); SHO: Standart hata ortalaması; Ös: Önem seviyesi.

Hücre duvarı içeriklerinin otlarda sindirilemeyen unsurlar olduğu bilinmektedir. In vitro gaz üretiminde gaz üretim miktarı yemin içerisinde bulunan fermente olabilen besin maddeleri ile doğrudan ilişkilidir. İnkübasyonda üretilen gazın fazla olabilmesi için rumende fermantasyona giren karbonhidrat miktarının da fazla olması gereklidir (Blümmel ve Orskov,. 1993). Bitki gelişiminin ilerlemesiyle ilişkili olarak bitki bünyesinde bulunan karbonhidrat miktarı azalmakta buna bağlı olarak gaz üretim miktarı da azalmaktadır. $\mathrm{ME}$ ve $\mathrm{OMSD}$ hesaplanırken gaz üretim miktarı, ham protein değeri, ham kül ile ham yağ içeriği parametreleri kullanılmaktadır (Menke ve Steingass, 1988). Sirken otunun ME ve OMSD'nin azalmasının sebeplerine bakıldığın da ham protein ve gaz üretim miktarının azalması, hücre duvarı unsurları olan ADF ve NDF içeriklerinin artmasından kaynaklanmaktadır. Sirken otunun olgunlaşmasıyla beraber metan (ml) üretiminin azaldığı görülmektedir. Toplam üretilen gaza metan oranlandığı zaman metan üretimi bitkinin olgunlaşmasıyla birlikte arttığı görülmektedir. Inkübasyon sonucunda üretilen gazın içeriğinde bulunan metan gazı oranı baz alınarak o yemin antimetanojenik kapasitelerini, düşük seviye (>\%11 ve $\leq \% 14)$, orta seviye (\%>6 ve $\leq \% 11)$ ve yüksek seviyede $(\%>0$ ve $\leq \% 6)$ potansiyele sahip olarak nitelendirilebileceği bildirmiştir (Lopez ve ark., 2010). $\mathrm{Bu}$ yapılan sınıflamaya göre Sirken otunun metan üretim değeri \% 15.61 ile 19.35 arasında değişmekte olup antimetanojenik bir etkisinin olmadığı görülmüştür.

\section{Sonuç ve Öneriler}

Araştırmadan elde edilen sonuca göre; olgunlaşma dönemleri Sirken otunun kimyasal kompozisyonunu ve besleme değerini önemli derecede etkilemiştir. Olgunlaşma döneminin ilerlemesiyle Sirken otunun mevcut besleme değeri düşmüştür. Olgunlaşma dönemlerinden ilk iki dönemde ham protein ve metabolik enerji bakımından bakıldığında çok iyi derecede olduğu görülmektedir. Bu bitkinin içermiş olduğu oksalatlar sebebi ile zehirli olabileceği bu yönüyle de araştırılması gerekmektedir. Eğer oksalatlar toksik sınırın altında ise bu dönemlerde ya hayvanlara otlatılarak veyahut biçilerek verilmesi tavsiye edilmektedir. Bundan sonra yapılacak olan çalışmalarda olgunlaşma dönemlerinin, Sirken otunun ruminant hayvanlarda yem tüketim alışkanlıklarına olan etkilerini belirlemek için in vivo sindirim denemelerinin yapılması tavsiye edilmektedir.

\section{Kaynaklar}

Anwar, M., 2006. The Pharmacognostic and Pharmacological Studies on Medicinal Valued Herbal Drugs Erythrina variegata var. orientalis, Matricaria chamomilla, Psoralea corylifolia and Chenopodium album. PhD Thesis. Department of Pharmacognosy, Faculty of Pharmacy, University of Karachi Pakistan, 43-49 pp.

AOAC, 1990. Official Method of Analysis. Association of Official Analytical Chemists, $15^{\text {th }}$ Edition, Washington, DC. USA.

Baytop, T. 1999. Turkiyede Bitkilerle Tedavi. Nobel Tip Kitapevi.

Blummel, M., Orskov, E.R, 1993. Comparison of an in vitro gas production and nylon bag degradability of roughages in predicting feed intake in cattle. Animal Feed Science Technology, 40: 109-119.

Bhargava, A., Shukla, S., Ohri, D. 2003a. Genetic variability and heritability of selected traits during different cuttings of vegetable 
Chenopodium. The Indian Journal of Genetics and Plant Breeding, 63(4): 359-360.

Bhargava, A., Shukla, S., Ohri, D. 2003b. Relative selection efficiency for foliage yield and quality characters in vegetable Chenopodium over different cuttings. Journal of Applied Horticulture, 5(2): 85-86.

Buxton, D.R. 1996. Quality related characteristics of forages as influenced by plant nvironment and agronomic factors. Animal Feed Science Technology, 59(1-3): 37-49.

Cacan, E., Ulger, I., Kilic, O., Yilmaz, M.F., Kokten, K., Kaplan, M. 2017. Potential Nutritive Value of Astragalus Species Harvested at Three Different Maturity Stages. Applied Acology and Environmental Research, 15(4): 2071-2080.

Canbolat, O. 2012 Potential nutritive value of field bindweed (Convolvulus arvensis L.) hay harvested at three different maturity stages. Journal of the Faculty of Veterinary Medicine, Kafkas University, 18 (2): 331-335.

Davis, P.H. 1965. Flora of Turkey and East Aegean Islands. Vol: 1-10, Edinburg.

Goel, G, Makkar, H.P.S., Becker, K. 2008. Effect of Sesbania sesban and Carduus pycnocephalus leaves and Fenugreek (Trigonella foenumgraecum L.) seeds and their extract on partitioning of nutrients from roughage-and concentrate-based feeds to methane. Animal Feed Science Technology, 147(1-3): 72-89.

Guerrero, J.L.G., Torija Isasa, M.E. 1997. Nutritional composition of leaves of Chenopodium species (C. album L., C. murale L. and C. opulifolium Shraeder). International journal of food sciences and nutrition, 48(5): 321-327.

Guven, I. 2012. Effect of species on nutritive value of mulberry leaves. Journal of the Faculty of Veterinary Medicine, Kafkas University, 18 (5): 865-869.

Kamalak, A., Canbolat, O. 2010. Determination of nutritive value of wild narrow-leaved clover (Trifolium angustifolium) harvested at three maturity stages using chemical composition and in vitro gas production. Tropical Grassland, 44(2): 128-133.

Kamalak, A., Atalay, A. I., Ozkan, C.O., Kaya, E., Tatliyer, A. 2011. Determination of potential nutritive value of Trigonella kotshi Fenzl hay harvested at three different maturity stages. Journal of the Faculty of Veterinary Medicine, Kafkas University, 17(4): 635-640.

Kaplan, M., Kamalak, A., Kasra, A.A., Guven, I. 2014a. Effect of maturity stages on potential nutritive value, methane production and condensed tannin content of Sanguisorba minor hay. Journal of the Faculty of Veterinary Medicine, Kafkas University, 20(3): 445-449.

Kaplan, M., Kamalak, A., Ozkan, C.O., Atalay, A.I. $2014 b$. Effect of vegetative stages on the potential nutritive value, methane production and condensed tannin content of Onobrychis caput-galli hay. Journal of the Faculty of Veterinary Medicine, Harran University. 3(1): 1-5.

Kaya, E., Kamalak, A. 2012. Potential nutritive value and condensed tannin contents of acorns from different oak species. Journal of the Faculty of Veterinary Medicine, Kafkas University, 18(6): 1061-1066.

Lopez, S., Makkar, H.P.S., Soliva, C.R. 2010. Screening plants and plant products for methane inhibitors. In "In vitro screening of plant resources for extra nutritional attributes in ruminants: Nuclear and related methodologies", Ed; Vercoe PE, Makkar HPS, Schlink A, London, New York, USA.

Menke, H.H., Steingass, H. 1988. Estimation of the energetic feed value obtained from chemical analysis and in vitro gas production using rumen fluid. Animal Research and Development, 28: 7-55.

Menke, K.H., Raab, L., Salewski, A., Steingass, H., Fritz, D., Schneider, W. 1979. The estimation of digestibility and metabolizable energy content of ruminant feedstuffs from the gas production when they incubated with rumen liquor in vitro. Journal of Agricultural Science (Cambridge), 92: 217-222.

Özer, Z., Önen, H., Tursun, N., Uygur, F.N. 1999. Türkiye'nin Bazı Önemli Yabancı Otları. GOP Üniversitesi, Ziraat Fakültesi Yayınları No: 38, 434 s., Tokat.

Stavarache, M., Samuil, C., Popovici, C.I., Tarcau, D., Vint, V. 2015. The productivity and quality of alfalfa (Medicago sativa L.) in Romanian forest stepe. Notulae Botanicae Horti Agrobotanici, 43(1): 179-185.

Uygur, F.N., Koch, W., Walter, H. 1986. Çukurova Bölgesi Buğday-pamuk ekim sistemindeki önemli yabancı otların tanımı. PLITS, 1986/4 (1): 169.

Van Soest, P.J., Robertson, J.B., Lewis, B.A. 1991. Methods for dietary fiber, neutral detergent fiber, and nonstarch polysaccharides in relation to animal nutrition. Journal of Dairy Science, 74(10): 3583-3597. 